American University Washington College of Law

Digital Commons @ American University Washington College of

Law

Articles in Law Reviews \& Other Academic Journals

Scholarship \& Research

2018

Justifying India's Patent Position to the United States

International Trade Commission and Office of the United States

Trade Representative

Sean Flynn

Srividhya Ragavan

Brook Baker

Follow this and additional works at: https://digitalcommons.wcl.american.edu/facsch_lawrev

Part of the Agriculture Law Commons, Intellectual Property Law Commons, and the International Trade Law Commons 


\title{
Justifying India's Patent Position To The United States INTERNATIONAL TRADE COMMISSION AND OFFICE OF THE UNITED STATES TRADE REPRESENTATIVE
}

\author{
Srividhya Ragavan, Sean Flynn é Brook Baker*
}

\section{INTRODUCTION}

On August 2, 2013, the Chairman of the Senate Committee on Finance and the House Committee on Ways and Means Committees using the powers under section $332(\mathrm{~g})$ of the Tariff Act of $1930^{1}$, requested the U.S. International Trade Commission (ITC) to institute an investigation ${ }^{2}$ on issues relating to Trade, Investment, and Industrial Policies in India, with particular reference to its effects on the United States. In their request, the Committee requested the ITC to conduct an investigation regarding Indian industrial policies that discriminate against U.S. imports and investment for the sake of supporting Indian domestic industries, and the effect that those barriers have on the U.S. economy and U.S. jobs. ${ }^{3}$ Following this, the Secretary of the US ITC instituted the investigation formally requesting reports at a public hearing to particularly determine the competitiveness of India's economy by examining whether India had any significant restrictive trade and FDI policies currently maintained

* Srividhya Ragavan, Professor of Law, University of Oklahoma College of Law, Norman, OK - 73034;

Sean Flynn, Associate Director and Lecturer in Law, American University Washington College of Law, Program on Information Justice and Intellectual Property, Washington D.C. 20016;

Brook Baker, Professor of Law, Northeastem University School of Law, Boston, MA 02115 .

19 U.S.C. $\$ 1332(\mathrm{~g})$

ITC Investigation No. 332-543

International Trade Commission, Notice for Investigation No. 332-543, Aug. 29, 2013. See also Federal Register, Vol. 79, No. 2, FR Doc. 2013-31487, Jan. 3, 2014 (notice of the USTR) 
or recently adopted and whether exports of US firms are affected and the measure of such effect. The investigation focused on agriculture, manufacturing and service sectors, as well as the overall business environment. ${ }^{4}$ The ITC's overview particularly considered changes in tariff and nontariff measures, including measures relating to the protection of intellectual property rights, and other actions taken by India's government to facilitate or restrict the inflow of trade and FDI.

The paper below largely is an extract of the testimonial filed by the authors to the Secretary of the ITC in response to the Notice on the Federal Register dated August 29, 2013 titled Trade, Investment, and Industrial Policies in India: Effects on the U.S. Economy. Where required, the paper also draws from the written submissions that the authors made to the United States Trade Representative's (hereinafter, USTR) office on the related question of whether India deny adequate and effective protection of intellectual property rights or deny fair and equitable market access to U.S. persons who rely on intellectual property protection. ${ }^{5}$ The authors submitted the testimonials to the I'TC as well as the US'R and as legal academics with expertise in patent law, trade law, the TRIPS agreement and the law of India. Each of the authors had engaged in this field for more than 10 years and has closely followed the developments within India in relation to the prescriptions of the TRIPS agreement.

\footnotetext{
4 See International Trade Commission, Notice for Investigation No. 332-543, Aug. 29, 2013

5 See Post-hearing submissions of Ragavan, Flynn and Baker, Notice of the USTR, Federal Register, Vol. 79, No. 2, FR Doc. 2013-31487, Jan. 3, 2014
} 
The authors, as legal academics asserted the core point that, whatever effect India's policies may have on the profits on multinational companies, including those headquartered in the U.S., India's recent enactment and implementation of its patent law is fully in accord with the World Trade Organization's Agreement on Trade Related Aspects of Intellectual Property Rights (TRIPS). ${ }^{6}$ Further, the authors asserted that India has demonstrated its adherence to TRIPS and to non-protectionism and a national treatment regime by revamping its systems, instituting massive changes to further intellectual property rights and by establishing prudent IP standards that apply equally to both domestic and foreign companies. Each of these standards remains in conformity with the TRIPS agreement and carefully calibrated to accommodate its national objectives within the scope of the flexibilities accorded under the TRIPS agreement.

The authors further reiterated that countries remain free after TRIPS to tailor their intellectual property laws to their domestic social, economic and cultural needs as they define them, within the bounds of the treaty. Accordingly, as recognized within the World World Trade Organization and the TRIPS Agreement, there is a great deal of lawful pluralism among WTO Members about standards of patentability and about key flexibilities, including both patentable subject matter and grounds for compulsory licenses. India's laws and

\footnotetext{
Annex IC to the General Agreement on Tariffs and Trade, Uruguay Round, World Trade Organization, done at Marrakesh, Apr. 15, 1994, 33 I.L.M 1981 (1994), reprinted in WORLD TRADE ORGANIZATION, THE RESULTS OF THE URUGUAY ROUND OF MULTILATERAL TRADE NEGOTIATIONS 365 (1995). See also Paris Convention for the Protection of Industrial Property, Mar. 20, 1883, 21 U.S.T. 1583, 1630, 828 U.N.T.S. 305, 307 (last revised July 14, 1967) (hereinafter Paris Convention).
} 
implementation thus far remain well within the lawful pluralism allowed by TRIPS.

Specifically, the authors added that TRIPS Article 31 permits compulsory licenses for ANY reason, including the historically sanctioned grounds of insufficient working of an invention in the country. This flexibility was explicitly clarified in the 2001 Doha Declaration on the TRIPS Agreement and Public Health. Similarly, TRIPS leaves countries free to define patentability criteria, including to define what is not an invention. Along the same lines, each member of the WTO has the sovereign right to determine and establish the threshold for the nonobviosuness/inventive-step requirement. Thus, the authors asserted that India is within its rights to establish that the new forms or uses of existing and known molecules that do not significantly increase the therapeutic effectiveness of such substances are not entitled to patent protection. Finally, the authors pointed out that most of the questions on the survey used by ITC remained irrelevant to the task of ascertaining whether India's policies violate TRIPS.

With that as the background, the following paper highlights the submissions and testimonials of the authors at the I'TC. The paper can be divided into two main parts. Part I responds to the issues that the ITC considered with reference to India's patent legislation. In this, the testimony traces the history of India's patents, outlines the recent changes that were implemented under the 2005 amendment to the legislation particularly highlighting how these changes remained 
fully TRIPS compliant. The second section ${ }^{7}$ addresses India's policies on agriculture and highlights how these policies are compliant with the TRIPS Agreement. The conclusion highlights that

\section{PART I: PATENTS}

\section{India Patent History:}

India, like many developing countries around the world, reformed its patent laws during its period of most rapid industrialization to tailor them to its domestic social and economic needs. What is important about this history is that the WTO TRIPS agreement restricted the range of options available to India and other countries in effecting such tailoring, but did not alter the goal itself. Indeed, the Preamble and Articles 7 and 8 of TRIPS clearly and forcefully posit that countries retain the sovereign ability to adjust their intellectual property laws and their implementation to serve local needs. The Preamble of TRIPS recognizes an "underlying public policy objective of national systems for the protection of intellectual property, including developmental and technological objectives." 8 Article 7 reiterates this position that the TRIPS' objective to protect and enforce IP rights "should contribute ... to a balance of rights and obligations" of members in a manner conducive to social and economic welfare. ${ }^{9}$ Article 8 recognizes members' rights to adopt

7 Professor Brook Baker did not sign on to the section on Agriculture submitted to the International Trade Commission.

8 Annex IC to the General Agreement on Tariffs and Trade, Uruguay Round, World Trade Organization, done at Marrakesh, Apr. 15, 1994, 33 I.L.M 1981 (1994), reprinted in WORLD TRADE ORGANIZATION, THE RESULTS OF THE URUGUAY ROUND OF MULTILATERAL TRADE NEGOTIATIONS 365 (1995) [hereinafter TRIPS] at art. 27(1).

9 Id. art. 7. 
public interest or public health measures consistent with the TRIPS provisions. ${ }^{10}$ The right of WTO Members to take local realities into account and to adapt TRIPS's minimum standards pluralistically is further clarified in TRIPS Article 1.1. ${ }^{11}$

Historically, India embraced process-patent-only protection in specified fields rather than product patent protection, particularly for food and pharmaceuticals, in order to prioritize domestic issues like access to medication and food security. India was not alone. In the period before TRIPS, nearly 50 countries exempted pharmaceuticals from product patent protection and an additional 10 exempted pharmaceuticals from process patents as well. ${ }^{12}$

The Indian Patent Act of $1970,{ }^{13}$ (IP70) along with other mechanisms such as drug and industrial policies were all part of the repertoire of tools used by India to achieve its national priorities. In gist, the process patent regime of IP70 excluded protection of the endproduct, but protected the method or the process of making the product. The process patent regime encouraged competitive innovation in the methods of making known products, thus, it enabled production of products patented elsewhere using different processes, incentivizing the development of more efficient production processes. The system's encouragement for process innovation was the first step to establishing India's generic drug industry, much like how Germany established its chemical process

\footnotetext{
$10 I d$. art. 8.

$11 \quad I d$. art. 1.1

12 PAul Goldstein, International InTEllectual Property LaW at 302 (2001).

13 See Patents Act of 1970, 27 India A.I.R. MANUAL 450 (1979) (hereinafter IP70).
} 
industries in the $1800 \mathrm{~s}$. Under IP70, the term of process protection over food, drug, and medical inventions was limited to five years. ${ }^{14} \mathrm{~A}$ license of right authorized any person to manufacture a patented product, without having to seek the patentee's approval. ${ }^{15}$ Inventions relating to food, chemicals, and pharmaceuticals, were automatically deemed to be endorsed with a license of right three years after the patent issues. Further, the government could, in the public interest, compulsorily license the patent if the invention was either not reasonably priced or not worked to satisfy the reasonable requirements of the public.

\section{Changes Under the 2005 Amendment:}

Many of these policies - although not their ultimate aims, were required to be changed by TRIPS. India has been faithful to its obligations under TRIPS, amending its Patent Act and taking many other measures at considerable expense to comply with its obligations while maintaining what flexibility it has under TRIPS to continue to further legitimate domestic policies. Indeed, in many respects India has been more forthcoming in amending its laws and policies to comply with TRIPS than has the United States.

\section{i. Pharmaceutical Product Patent Regime:}

India's most important TRIPS-fulfilling amendment-the institution of a pharmaceutical product patent regime - was instituted in 2005. India had previously adopted the TRIPS compliant international standard of patentability based on the requirements of novelty,

$14 I d . \$ 53(1)(\mathrm{a})(1979)$.

$15 I d . \$ 88$. 
inventive step, and industrial applicability (utility) with respect to other fields of technology. India was required to grant patents on pharmaceutical product inventions as well as process inventions because the TRIPS Agreement prevents discrimination against particular fields of technology.

India's definition of novelty or "new invention" includes world-wide prior art which was was much broader than the requirement that prevailed in the United States under 35 U.S.C. $\$ 102$, under which any use of the application material within the United States (only) defeated novelty. Only in 2011 would the America Invents Act introduce the concept of worldwide novelty, ${ }^{16}$ even though this provision was heavily criticized as obstructing small-scale industries.

India's imventive step requirement requires that the "feature of an invention that involves technical advance as compared to the existing knowledge or having economic significance or both and that makes the invention not obvious to a person skilled in the art." ${ }^{17}$ This requirement for inventive step has been widely noted as being much more stringent than the nonobvious requirement in the United States, but many countries have different, indeed stricter standards for inventive step than does the United States. ${ }^{18}$ In fact, the U.S.'s

16 Leahy Smith America Invents Act, Pub. L. 112-29, (H.R 1249) at $\$ 102$.

17 Patents (Amendment) Act, 2005, No. 15, Acts of Parliament, 2005, at $₫$ 2(ja) (hereinafter PTA, 2005); See also Srividhya Ragavan and Feroz Ali Khader, Proof of Progress: The Role of Obviousness Standard in the Indian Patent Office, GLOBAL PERSPECTIVES ON PATENT LAW (FORTHCOMING). Ed. Ruth Okediji, Margo Bagley, Jay Erstling. Oxford University Press, 2014 (discussing how the standards of obviousness in India sets a higher bar when compared to the United States).

18 See, e.g., Amy Nelson, Obviousness or Imventive Step as Applied to Nucleic Acid Molecules: A Global Perspective, 6 N.C. J. L. \& Tech. 1 (2004); Request for Comments on the International Effort to Harmonize the Substantive Requirements of Patent Law, 66 Fed. 
weak standard has been a significant causative factor for the degenerating quality of the patents in the U.S.

India has also adopted, within the framework of allowable pluralism under TRIPS, a stronger definition of industrial applicability than the United States. The United States' weaker standard of utility has historically allowed the patenting of business methods and other more abstract innovations, unlike India and many other countries that either exclude such matters as unpatentable or consider them not to have industrial applicability. This is one of many permissible policy differences allowed under TRIPS. In this regard, it is also important to note that India has codified a number of exclusions to patentability that are similarly excluded by many other countries - abstract ideas, theories of science, plants and animals, etc., even where the same creations could subject to patent in the U.S. Perhaps the most important exclusion from patentability, discussed further below, is India's Section 3(d).

ii. Section 3(d): ${ }^{19}$

Section 3(d) does the important function of segregating patents that result in evergreening from those that represent a true innovation. Basically, new forms of known compounds that exhibit enhanced efficacy will cross the threshold and be considered innovative. Other forms that merely represent a new form of a known substance without making any therapeutic contribution to the disease in

Reg. 15,409, 15,409-11 (Mar. 19, 2001) (listing seventeen differences between U.S. patent law and the law of other developed countries).

19 Id. at $\$ 3(\mathrm{~d})$ 
question will fail the bar. Unlike the suspicions expressed under the USTR's Special 301 report of 2013, section 3(d) does not represent an unauthorized fourth requirement because the applicability of this section is limited to one small question in one subject matter. ${ }^{20}$ Section 3(d) has no universal application, which would be essential had it been conceived as a fourth requirement. Similarly, the requirement in section $3(\mathrm{~d})$, as mentioned earlier, is no different from the requirement imposed for similar compositions in the United States. That is, in the United States, the Manual for Patent Examination Procedure in sections 716.02 and 2144.09 at paragraph VII discuss the use of "unexpected advantages" or "superior properties" to determine obviousness of such structurally similar compounds. ${ }^{21}$ Further, the Court of Appeals for the Federal Circuit in several decisions has reiterated the requirement of "unexpected results" or "surprising effect" as tests to determine patentability of the new forms of known substances. ${ }^{22}$ These kinds of criteria are not measurably different form the efficacy requirement that India uses to assess patentability.

Granting secondary patents, which promotes evergreening, is a controversial issue not just in India but also in the United States. ${ }^{23}$ The term evergreening refers to strategically patenting different forms of a medicine's active ingredients, new uses, and/or new

\footnotetext{
20 See 2013 Special 301 Report, Office of the United States Trade Representative, available at www.ustr.gov

21 Manual of Patent Examination Procedure, at sections 716,2144 available at www.uspto.gov.

$22 I d$.

23 See Generic Drug Entry Prior to Patent Expiration: An FTC Study. Federal TRADE COMMISSION 2002
} 
formulations and staggering such protection to extend monopoly control over various forms/uses of the medicine beyond the 20 -year term of protection. The steady lowering of standards, especially for determining non obviousness, has in turn contributed to such strategic patenting, which is now subject of much scrutiny in the United States.

The struggles of the United States with a barrage of secondary patents on medicines have served as a lesson to other countries, including India. ${ }^{24}$ In essence, India is trying hard to prevent issues that the United States is currently facing on account of unduly lowering the bar to facilitate more patents. In gist, low patent standards can dangerously interfere with follow-on innovations and unjustly reward very low levels of innovation. For countries like India, the effect of such lowering on innovation is quite onerous in terms of pharmaceutical costs and untreated patients. Thus, it is important to appreciate that invalidating patents of multinational companies is not a sign of TRIPS noncompliance as long as such invalidation is done using lawful patentability standards and nondiscriminatory processes as required by the TRIPS agreement. In the United States such patents are easily issued although they can be invalidated by litigation. But, rather than accepting the resource investment, cost, judicial time and the loss of access to the public inherent in the U.S. model for combating evergreening, India's

24 See Thomas Faunce and Joel Lexchin, Linkage' Pharmaceutical Evergreening in Canada and Australia, Aust -New Zealand Health Policy (Biomed Central) (2007); EvergreEnING of Pharmaceutical market protection, European Generic medicines ASSOCIATION. 
Section 3(d), enacted in the 2005 amendment, ${ }^{25}$ prohibits patenting of new uses of known substances, including medicines. Similarly, patenting new forms of known substances is not allowed unless there is evidence of significantly enhanced efficacy. The logic of this interesting provision is along the exact lines of the opinion of the Court of Appeals for the Federal Circuit (CAFC) in the case of Pfizer v. Apotex involving the Pfizer's patenting of the besylate form of amlodipine (salt form) which Apotex claimed was obvious in the light of Pfizer's own patent on the base compound amlodipine. ${ }^{26}$ The CAFC, in agreeing with Apotex that the patent on the besylate form was invalid, highlighted the besylate form lacked the unexpected superior results from the base compound in order for the salt form to be patented. ${ }^{27}$ Indeed, the Manual for Patent Examination Procedure in section 716.02 and in 2144.09 specifically memorializes unexpected results as a test to demonstrate nonobviousness of structurally similar compounds like isomers and homologues. ${ }^{28}$ Thus, India's standard is well within the lines of what has been allowed in the United States.

The Novartis judgment, which has become central to Congressional criticism of India's IP regime, was decided significantly on the basis of the absence of any evidence of enhanced efficiency, a valid criteria for assessing patentability as described above. ${ }^{29}$ In essence, the Supreme Court of India, in a well-reasoned decision, found that betacrystalline form of imatinib mesylate, was revealed and claimed in a

25 PTA, supra note 9, $\ 3(\mathrm{~d})$.

26 Pfizer v. Apotex, 488 F. 3d 1377 (Fed. Cir. 2007); see also Pfizer v. Apotex, 480 F.3d 1348 (Fed. Cir. 2007).

27480 F.3d at 1368; see also In re Swain, 33 C.C.P.A. 1266, 156 F.2d 246, $247-48$ (1946).

28 Manual for Patent Examination Procedure $\$ 2144, \$ 716$ (8th ed., rev. 2012).

29 Novartis AG v. Union Of India \& Ors, Civil Appeal No. 2706-2716 of 2013. 
pre-TRIPS patent and thus was time barred from patentability in India unless it showed significantly enhanced efficacy. ${ }^{30}$ Unfortunately for Novartis, the Supreme Court of India found that Novartis offered no evidence of increased efficacy of the relevant compound whatsoever, and thus that the patent was unmeritorious under section 3(d). ${ }^{31}$ Whatever the effect ton Novartis's bottom line or on balance of payments with the U.S., this was an eminently reasonable, and TRIPS-permissible, decision.

TRIPS does not require its member countries to be persuaded by the issue patents of other countries. The argument that several other countries agreed that Gleevec was patentable despite being a mere variation of an existing, previously patented chemical entity is inconsequential to India's own patent determination. If a country chooses to adopt a higher bar for determining patentable subject matter and/or inventive step under TRIPS, it is well within the member's rights to do so. Indeed, Japan has a record of allowing approximately $14 \%$ of patents that are granted in the United States. Having a higher bar with standards is well within the rights of a sovereign nation and well-established under the principles of the World Trade Organization. India's Section 3(d) and the Novartis judgment fall well within the ambit of the TRIPS agreement.

Indeed, as India transitions into a full-fledged patent regime, it is well-worth remembering Justice Breyer's cautionary note in Laboratory 
Corporation v. Metabolite: 32 "sometimes [patents] presence can discourage research ..., by requiring complex licensing arrangements, and by raising the costs of using the patented information, sometimes prohibitively so. ${ }^{.33} \mathrm{He}$ advocates that patent law should carefully seek to avoid the dangers of overprotection just as surely as it should avoid diminished incentives resulting from under protection. ${ }^{34}$ Section 3(d) is an important tool to serve the end of rewarding true innovation while refusing to grant exclusive rights for trivial, incremental changes. Further, in instituting section $3(\mathrm{~d})$ and in setting a higher patentability bar, a developing country like India would rightly avoid the some of the excessive patenting problems that seem to plague the United States.

\section{iii. Opposition Procedure:}

Another important feature, the opposition mechanism, embodies a pre- as well as a post-grant opposition procedure. ${ }^{35}$ Pre-grants opinions conserve administrative time otherwise spent on examining a patent application that could later be invalidated, in addition to preserving judicial time. As for the procedure, under $₫ 25$, any third party can oppose a patent after publication of the application and before the grant for reasons of patentability, wrongful acquisition, inadequate disclosures, etc. ${ }^{36} \mathrm{On}$ similar grounds, any interested person may oppose the patent within one year of the grant of

\footnotetext{
32 Lab. Corp. of Am. Holdings v. Metabolite Labs., Inc., 548 U.S. 124, 127, 126 S. Ct. 2921 $33 \quad I d$

$34 \mathrm{I} d$.

35 PTA, supra note 9, at, $\iint 18,35$.

$36 I d ., \$ 25$ (c), (e), (h).
} 
patent. ${ }^{37}$ The grant structure circumvents one of the India's debilitating constraints, being the backlog in the judicial system. Hence, the grant opinions seemingly have more economic value when compared to the USP'TO's administrative opinions, for instance, not least because there are few judicial opinions on the question of inventiveness, but perhaps also because of the influence of a combination of other factors such as the time taken to resolve disputes in India.

WIPO has researched opposition procedures in depth and found substantial variation in countries approaches to both pre- and postgrant procedures, but clearly does not consider them unauthorized by TRIPS. Indeed, TRIPS Article 62.4 explicitly references and thus indirectly condones the use of opposition procedures.

\section{iv. Intellectual Property Office Modernization:}

When India amended its patent legislation, the government of India through the Department of Commerce modernized the different intellectual property offices at great expense. ${ }^{38}$ Additionally, India has worked to relieve patent disputes from the most debilitating constraint of all: the Indian Court system. India has established the Intellectual Property Appellate Board (IPAB), as the special appellate administrative tribunal from 2007 to hear patent appeals from the decisions of the Controller (provided it includes a technical

37 Id., 89, § 25(k);

38 Press Release, Department of Commerce (India), Government's Initiatives in Revamping Intellectual Property Show Results (Feb. 7, 2002). 
member). ${ }^{39}$ Akin perhaps, to the Court of Appeals for the Federal Circuit in the United States, the review of the decision of the IPAB can be sought by the losing party by filing a writ petition on the grounds that there is a question of law requiring the attention of the High Court or that there is illegality or miscarriage of justice. The Supreme Court of India has established that all decisions of tribunals including the IPAB are subject to review before the Division Benches of the High Court (two-judge benches) within whose jurisdiction the concerned tribunal falls. ${ }^{40}$ The establishment of the IPAB signifies India's commitment to implementing the patent statute.

\section{v. Compulsory Licensing:}

India has one of the most sophisticated compulsory licensing provisions of any country -- one that fully conforms to the TRIPS agreement as clarified by the Doha Declaration.

Section 84 of the Indian patent statue allows the government to compulsorily license a patent three years after grant. ${ }^{41}$ Applicants seeking compulsory licenses should provide proof that the applicant attempted to negotiate a license with the patent owner as required under the TRIPS agreement, and must do so for a minimum period of six months. ${ }^{42}$ As for the grounds, third parties can seek a license on the grounds that the (a) reasonable requirements of the public

39 Notifications No.12/15/2006-IPR-III (2/4/2007), Ministry of Commerce \& Industry, (India).

40 L. Chandra Kumar v. Union of India \& Others, AIR 1997 SC 1125 (1997) (India); See also Union of India v. R. Gandhi, President of Madras Bar Association, (2010) 5 SCALE 514.

41 See PTA, supra note 9, at $\$ 84$

$42 I d ., \S 84(5)(4)$. 
with respect to the patented invention have not been satisfied, (b) that the patented invention is not available to the public at a reasonably affordable price, or (c) that the patented invention is not worked in the territory of India. ${ }^{43}$ The term reasonable requirements of the public is broad and can be deemed to be not satisfied if an existing industry or trade in India is affected; the demand for a patented article is not met by the patent holder, or the market is affected directly or because of the patent holder's activities. These grounds are fully in accord with traditional grounds for compulsory licenses dating back to the earliest patent laws, and explicitly sanctioned in Paris Convention Article 5(A).

Under Section 92, a compulsory license can be granted where the government provides notice of the existence of a national emergency such as a public health crisis or where it intends to use the patented subject matter for non-commercial public use. ${ }^{44}$

Section 90(1)(vii) allows for export of non-predominate quantities compulsorily licensed products and Section 92A requires export of patented pharmaceuticals to "any country having insufficient or no manufacturing capacity in the pharmaceutical sector for the concerned product to address public health problems, provided compulsory licence has been granted by such country or such country has, by notification or otherwise, allowed importation of the patented pharmaceutical products from India.".

$43 I d ., 884$.

44 Id. $\$ 92$. 
India's provisions with reference to compulsory licensing are fully compliant under Article 31 of the TRIPS agreement. Generally, TRIPS allows countries to determine the grounds for issuing compulsory licensing. In any event, India has issued only one compulsory license so far and did so in a case where there was egregious pricing and lack of supply to the market. Although U.S. critics have focused on the local-working rationale of the Patents Office decision granting a compulsory license, there were in fact three independent grounds for the license: insufficient supply, excessive pricing, and lack of an adequately explained total failure to work locally. Each or any of these grounds, including local working, is legally sufficient and justified under international and national law. ${ }^{45}$ India was well-within its rights to issue the license on Bayer. ${ }^{46}$

In any event, the facts of the Bayer situation demonstrates that for the United States to expect India to not take steps because Bayer or other companies feel that is unfair would be at the cost of its political leadership position. In gist, at a time when India housed approximately 20,000 patients with liver cancer and about 9,000 patients with kidney cancer between the years 2008 to 2010, a negligible amount of Bayer's Sorafenib was imported into the country. In fact, no importation ensued in 2008, a year when Bayer recorded a worldwide profit of over $\$ 678$ million in the rest of the world. The patent holder's inability to fulfill its duty of catering to the demands of the market notwithstanding, Bayer's pricing of the drug

\footnotetext{
45 Michael Halewood, Regulating Patent Holders: Local Working and Compulsory Licenses Under International Law, 35 Osgoode Hall L.J. 243 (1997).

46 See generally, Srividhya Ragavan, Patients Win Over Patents, THE Hindu, (March 7, 2013).
} 
bordered on the ridiculous. The selling price which Bayer charged at an egregious price of Rs.2,80,428 per month (about $\$ 5,000$ ) was nearly five times higher than the median annual income in India. Indeed, as a mark of its careful scrutiny, the Indian patent office rejected an application to compulsorily license Dasatinib.

It is most important to consider the actual context of income inequality and excessive pricing in India, which minimizes U.S. sales and profits in India, as well as against the general trend of trade with India, which is quite profitable for the U.S. Overall, U.S. pharmaceutical exports have been steadily rising, as shown in the figure below: ${ }^{47}$

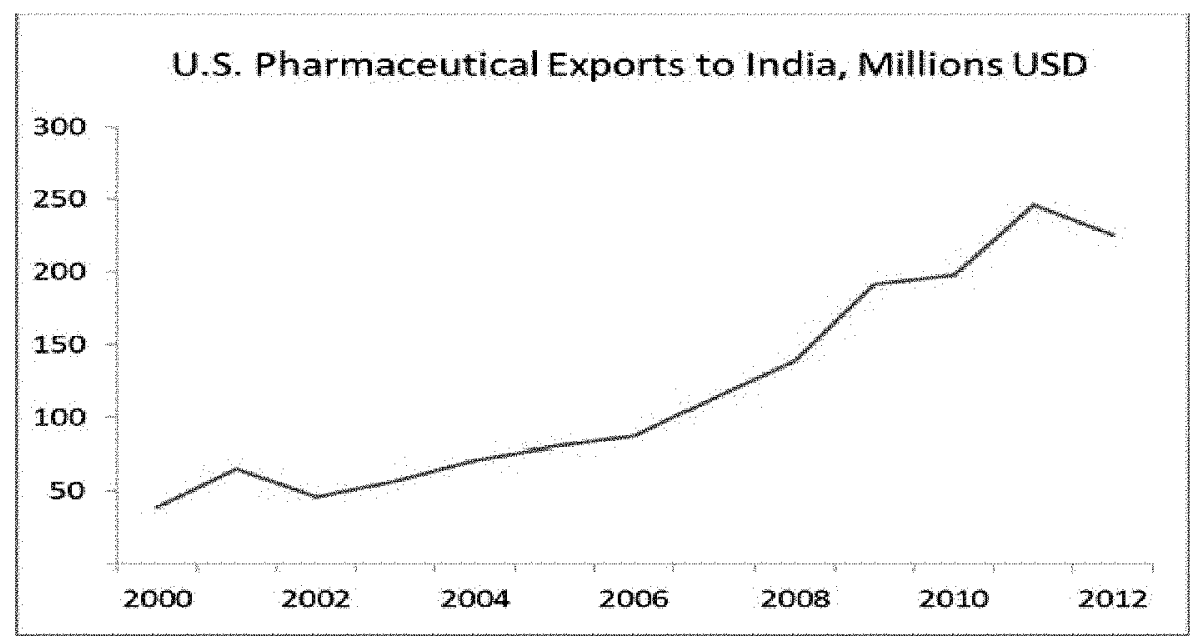

Source: World Trade Organization

47 From the post-hearing submissions of the authors to the USTR 
According to trade data from the World Trade Organization, U.S. pharmaceutical exports rose from $\$ 39$ million to $\$ 225$ million during the period $2000-2012$. This is an increase of $470 \%$.

Furthermore, U.S. pharmaceutical exports to India are growing at a faster rate than U.S. pharmaceutical exports to the world as a whole. Since the Patents Act was amended in 2005, export growth in India has outpaced overall world growth in six out of eight years.

\begin{tabular}{|c|c|c|}
\hline & 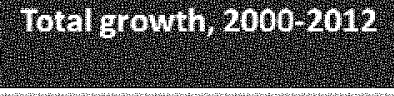 & $\begin{array}{l}\text { Avarage rown orep } \\
\text { proryer }\end{array}$ \\
\hline US. Exports to india & $470 \%$ & $18 \%$ \\
\hline U.S, Exports to World & $242 \%$ & $11 \%$ \\
\hline
\end{tabular}

Source: World Trade Organziation

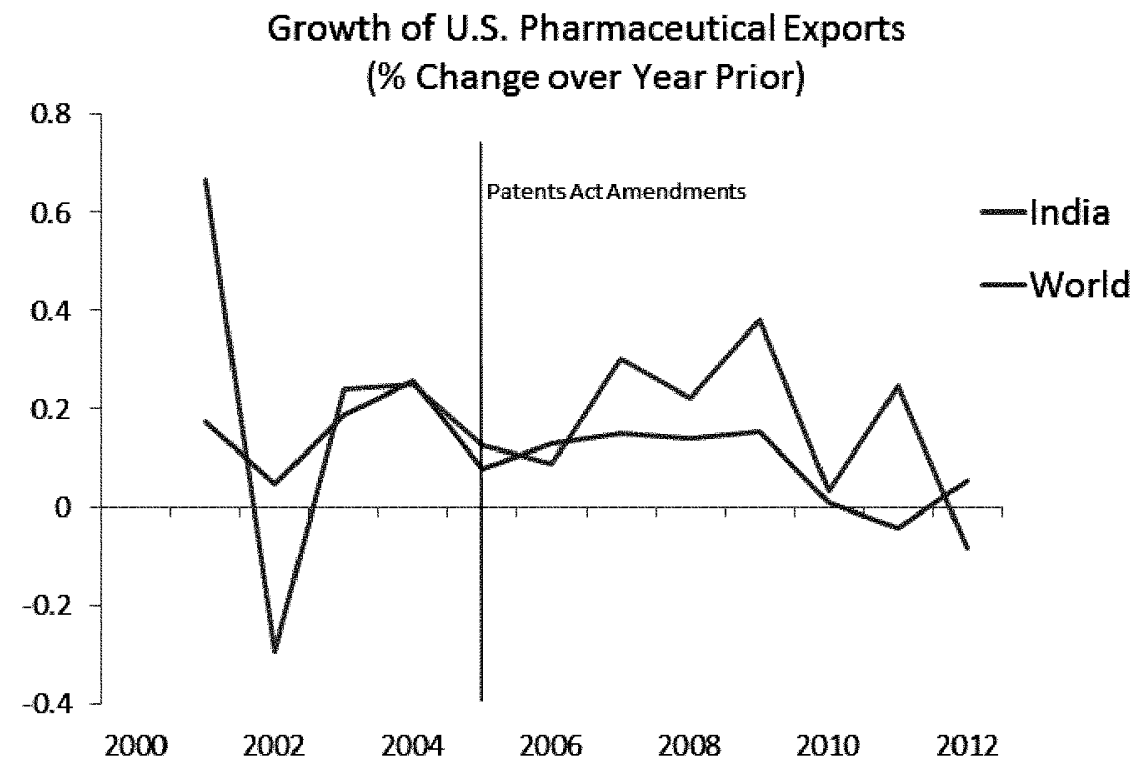

Source: World Trade Organization 
It is notable that there has not been a single compulsory license granted on an American product. The one compulsory license issued has been on a patent held by Bayer, a German firm.

\section{0}

Pharmaceutical patents granted in India, 2007-2012 (sowree. Indan patent ofice)

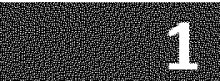

Compulsory license for a German pharmaceutical product

\section{0}

Compulsory licenses for U.S. pharmaceutical

Products

Bayer's market price and "access price" for Nexavar were both unaffordable to most of the Indian population.

\section{Nexavar Prices Versus Yearly Income in India by Quintile} (GNI, 2012)

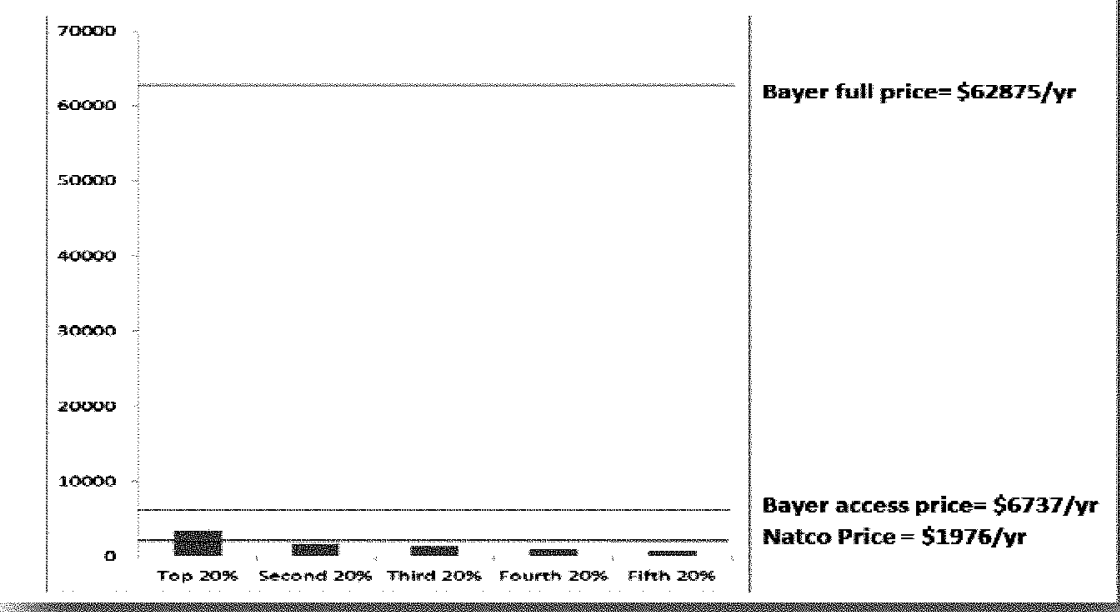

At the ITC hearings, representatives from Bayer, the National Association of Manufacturers, and others, noted that Bayer was making the drug available at a lower "access price" in India. 
However, if one converts the full price and access price to U.S. dollars (based on a January 2013 exchange rate) and compares them to the average annual income-by-quintile, the data shows that both prices exceed annual income of even the top $20 \%$.

Sources: Income and income distribution data from World Bank; Prices from the Nexaver compulsory license

This reality has to be weighed against the fact that in India, insurance coverage exists broadly for not more than about 5 to $20 \%$ of the population. ${ }^{48}$ Most Government sponsored schemes have a cap of Rs. 30,000 (approx.. \$500) and is limited to hospitalization. Further, domiciliary treatment (medication) is not covered as part of most insurance in India. ${ }^{49}$ Within this, the market shows enormous variations. Much of the insurance is privately acquired as opposed to Government sponsored or as part of employee benefits. It is estimated that the annual pay-out for those who have insurance is in the range of $\$ 1500$ - 2000 . $^{50}$

\section{vi. Bolar Provision:}

Sections 107A, a bolar-type or "early working" provision, introduced via the 2005 amendment, allows for storage of patented material during the patent term to facilitate marketing immediately after the expiration of the patent term. ${ }^{51}$ Use of the patent for research, data

\footnotetext{
48 E-mail from Professor Surupa Gupta, University of Mary Washington, (Feb 12, 2014) (on file with the author, Ragavan).

49 E-mail from Mr. D. G. Shah, Vision-India Limited, (Feb 23, 2014) (on file with the author, Ragavan).

50 E-mail from Professor Surupa Gupta, University of Mary Washington, (Feb 12, 2014) (on file with the author, Ragavan).

51 Patents Act, supra note 9, at $\$ 107(\mathrm{~A})$
} 
gathering, and seeking regulatory-approval, both domestically and abroad, are exempted from being construed as infringement. The New Delhi High Court approved the operation and the constitutionality of the provision in Bayer $v$. Cipla. ${ }^{52}$ Such regulatory exceptions fall within the ambit of Article 30 which allows every country to consider the legitimate interests of third parties in structuring such exceptions. Indeed, bolar exceptions have been considered in a WTO dispute opinion of a panel "Canada - Patent Protection for Pharmaceutical Products" - (adopted on 7 April 2000) upholding Canada's bolar and regulatory exceptions, similar to that of India's. Even though the U.S. has attempted to block the use of Bolar type provisions to allow a patent exception for purposes of exporting patent protected subject matter for purposes of obtaining regulatory approval in some of its bilateral and regional trade agreements, it is completely lawful for countries like India to allow such foreign registration as a limited exception under Article 30.

\section{vii. Exhaustion of Patent Rights:}

Section 107A(b) embraces an international exhaustion of the rights of a patent owner. ${ }^{53}$ Thus, the sale or importation into India of a legally procured patented item from anywhere in the world will not amount to infringement. ${ }^{54}$ That is, there is no need for authorization by the patentee or his assignee as long as the product was sold with due permission of the patent owner (or assignee). In fact, even importation of a product acquired from sources other than the patent

52 Bayer Corp. v. Union of India, (2009)41 PTC 634(Del).

53 PTA, supra note 9, \$ 107A(b)

54 Id. $₫ 107 \mathrm{~A}(\mathrm{~b})$. 
owner (or assignee), for instance, from countries not yet recognizing product patent protection, would be covered by the section. Article 6 of the TRIPS Agreement explicitly allows members to choose a regime of exhaustion and ensures that they be challenged under the W'TO dispute settlement system. The Doha Declaration, under paragraph 5, has reaffirmed that Members do have this right, stating that each Member is free to establish its own regime for such exhaustion without challenge. ${ }^{55}$

viii: Criticisms about revocation of patents in India

Several statements and submissions to the ITC and the USTR, including that of $\mathrm{BIO}$, criticized India for patent revocations through post-grant reviews by courts or the Patent Office. ${ }^{56}$

First, establishing judicial standards (or statutory interpretation) goes to the core of an independent judiciary. The General Obligations outlined from Article(s) 41 to 61 of the TRIPS agreement supposes the establishment of an independent judiciary with rights and authorities that are consistent with that sovereign government. Under traditional principles of international law, no country, much less industrial groups, can dictate the constituents of "judicial standards" of another country. The United States has not and will not tolerate

55 Annex IC to the General Agreement on Tariff $s$ and Trade, Uruguay Round, World Trade Organization, done at Marrakesh, Apr. 15, 1994, 33 I.L.M 1981 (1994).

56 See Bio's submission to the ITC, page 4 (complaining of "counterfeiting, large backlogs and patent office inefficiency, differing administrative, legal, and judicial standards for patentability, compulsory licensing, inadequate data protection, and a need for harmonization of substantive standards and processes across patent offices around the world. Issues unique to biotechnology include patentability of biotechnology inventions, double patent review systems, genetic resource access and benefit regimes, and technology transfer issues that involve intellectual property.") 
foreign interference into the functioning of its judiciary, and no other country should likewise accept such criticism.

Page 8 of the $\mathrm{BIO}$ submission complains specifically about several patent revocations:

The Indian Intellectual Property Appellate Board (IPAB) revoked several pharmaceutical patents in post-grant opposition proceedings in the last two years including patents protecting Sutent, Pegasys, Ganfort, Combigan, and Renadyl.

Notably, a close comparison of the reasoning used by the Indian patents office shows remarkable parallels to the reasoning used by U.S. courts to invalidate patents here in the United States. As an example, in the following paragraphs, I examine Ganfort \& Combigan's (which was one application for a combination drug) treatment in the United States.

In India, Ganfort and Combigan were covered by Patent No.212695 titled "Hypotensive Lipid (prostaglandin derivatives) and Timolol composition and methods of using same" The patent related to a fixed combination of Bimatoprost and Timolol. ${ }^{57}$ The patent was challenged as being obvious on the grounds that the only big difference between the invention and the prior art was that the invention was a single dose composition as opposed to separate administration of the combination. ${ }^{58}$ The patent was invalidated in India for not traversing the nonobviousness requirement.

57 Application for Patent bearing No. 219504

58 Anubha Sinha, IPAB revokes Allergan's patent on eye drugs Ganfort and Combigan, SpicyIP, (2013) 
The interesting aspect which BIO does not highlight is that fact that in Allergan Inc us. Sando ${ }^{59}$ a full panel Court of Appeals for the Court of Appeals for Federal Circuit in dealing with Combigen's claim one INVALIDATED the claim on the grounds that "unexpected results and prior art teaching away were NOT sufficient to outweigh the other evidence of obviousness."

Both timolol (a beta blocker) and brimodine (an alpha2-agonist) were commercially available in their claimed concentrations at the time of the invention and were used to treat opthalmic conditions. The primary prior art reference, DeSantis, expressly taught serially administering both a beta blocker, such as timolol, with a brimodine in a fixed combination. It also provided "an express motivation to combine alpha2-agonists and beta blockers in order to increase patient compliance." Slip Op. at 8 .

The equivalent in India of the unexpected results test used in the United States is the enhanced efficay. A Federal Circuit panel validated the method claim - with Judge Dyk filing a dissent asserting the invalidity of the claim.

Indeed, the IPAB opinion states that:

"We too are of the opinion like the Federal Court that there was a reasonable expectation of success in view

\footnotetext{
59 Allergan $\quad$ v. Sandoz, Fed. Cir, 2013 available at http://www.cafc.uscourts.gov/images/stories/opinions-orders/11-1619.Opinion.4-252013.1.PDF

$60 \quad I d$.
} 
of the DeSantis. Therefore for the above reason, we find that the invention is obvious." ${ }^{101}$

In India, a limited number of claims were filed and hence, only these were contested. In the U.S., even though Sandoz succeeded in establishing that claims of " 463 patent were invalid as obvious, the number of filed claims were more and the Federal circuit ruled that some of those claims ( 4 of 149) were not obvious, and that delayed the entry of the generic.

Similarly, with respect to the drug Pegasys, the application to patent was filed by Roche in 1997 for "pegylated interferon alfa2a." The application matured into a patent in 2006 bearing no. 198952. A postgrant opposition was filed by a local companies on the grounds that interferon is a known protein, which when conjugated with the polymer PEG through the process of PEGylatio (a process of covalent attachment of polyethylene glycol polymer chains to another molecule or therapeutic protein) achieves improved stability, solubility, and reduced immunogenicity. Interestingly, Roche was able to traverse this opposition at the patent office level. On appeal, the IPAB's explained its reasoning for invalidating the patent as obvious as follows:

"Interferon had already been used to treat hepatitis C. There were problems in the use of this protein as such. PEGylation was known from 1970s. Pegylation of proteins was known to improve the activity of the 
proteins. There was intense activity in the field of PEG chemistry and the person skilled in the art will be acquainted with it, if not directly involved in it. Linear conjugates of protein showed improvement over unconjugated protein. ...the person of skill In the art takes a look at Monfardini and also at the other exhibits. He knows that the activity of interferon has to be improved for Hepatitis $\mathrm{C}$ cases. He knows that linear pegylation will improve it a bit. He knows that branched pegylation has shown marked improvement over linear conjugates in the case of superoxide dismutase and three enzymes. He is confident that branched PEGylation of Interferon will work; it has worked in Monfardini with enzymes. Monfardini gives him the structure on a platter. He also knows that he can work with molecular weight range of 5000-40,000 daltons to strike oil. He has reason to believe that higher may be better."

It is understandable that Roche does not like the judgment - but the above paragraph(s) show case due process and a reasoned judgment in action.

Notwithstanding the above, India recorded at that time a total of 10 to 12 million patients suffering from Hepatitis $\mathrm{C}$ - for which Pegasys offered a treatment. A six-month treatment of pegasys cost approximately Rs. 4,36,000 lakhs (approx. \$ 8400!) and was discounted at a price of approximately Rs. 3,14,000 lakhs (\$6000). 
The drug is taken in combination with Ribavarin, which cost approximately another Rs. 47,000 thousand (\$1000). Given the cost, roughly, a total of 1400 patients were treated. ${ }^{62}$ Yet, it was patented in India until it was invalidated and was NOT ever subject to compulsory licensing.

Similarly, another drug cited by BIO - Sunitinib, (Sutent) - whose 50 mg tablets were marketed by Pfizer for an exorbitant price of Rs. 61,000 for a strip of seven tablets (\$1200 approximately) was also not subject to compulsory licenses. What BIO does not add here is the fact that its members cannot sell these drugs even to its American patients at this price, save for "the $1 \%$ " in this country. ${ }^{63}$

Similarly, many of the other issues_that BIO as well as other industry groups like PhRMA decry equally_lack_adequate basis. For instance, in Mayo v. Prometheus ${ }^{64}$ a unanimous Supreme Court struck down a method of medical treatment claim as being directed to a law of nature and thus patent ineligible! Thus, exclusions from patentability are not alien to the U.S. legal system. Other countries exclude such claims from protection. For example, in Canada methods of medical treatment are not patentable under section section 12.04 .02 of its Manual of Patent Office Procedure. Further, TRIPS Article 27.3 further allows for such exclusions.

As for revocation of patents, BIO's and this industry group's statement leaves the impression that revocation of patents is a rare

62 Id.

63 Prashanth Reddy, Estimating the number of Hepatitis patients treated by Roche's Pegasus (2012)

$64 \quad 132$ S.C. $1289(2012)$ 
and unusual phenomenon! The following data examines two hundred and eighty (283) three cases where Federal District Courts have examined the patent validity between 2007 and 2011. Of the 283 cases identified, only in 39 cases were the claims determined to be valid. The following table provides a detailed summary:

\begin{tabular}{|l|l|l|l|l|l|l|l|}
\hline Patent Cases in District Courts involving validity by Year \\
\hline & 2007 & 2008 & 2009 & 2010 & 2011 & Total \\
\hline Cases where claims in patent held invalid & 46 & 49 & 54 & 49 & 45 & 243 \\
\hline Cases where claims in patent held valid & 12 & 8 & 11 & 5 & 3 & 39 \\
\hline Percent where claims in patent held valid & $20 \%$ & $14 \%$ & $17 \%$ & $9 \%$ & $6 \%$ & $14 \%$ \\
\hline Total & 58 & 57 & 65 & 54 & 48 & 283 \\
\hline
\end{tabular}

About 243 of the 283 cases had claims that were invalidated by the District Court. That is, in a whopping $86 \%$ of the total cases examined, claims were invalidated.

The Court of Appeals for the Federal Circuit is also not shy of invalidation of claims where the court believes is warranted. The following graph provides the number of patents invalidated by the Court of Appeals for the Federal Circuit from 2002 to 2012. 


\section{Chart 2: Percent of Patents Invallidated Per Year by the Federal circuit}

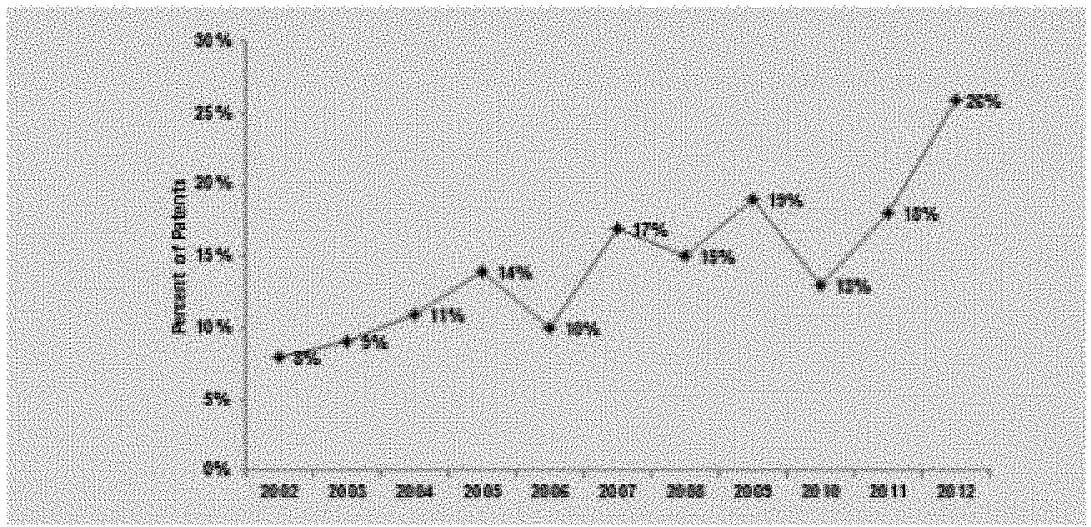

Source: White Paper Report; United States Patent Invalidity Study, 2012.

Revoking patents merely point to a robust judiciary reviewing imperfect decisions by harried patent examiners. Several of the submission decries patent revocations in India as if denials/revocations/invalidations never occur anywhere else. The sophistication of a patent system is not in the numbers of patents issued. It is in the quality of patents. Decreasing the bar for patenting in the United States is cited as a reason for the Supreme Court's unprecedented activity in this area of law. Academics have decried the pathetic quality of patents in this country. Forums like the International Trade Commission has a burden to ensure that it does not set the United States on a course to punish others countries for instituting quality based standards. 


\section{PART II: AGRICULTURE}

India, like other developing nation counterparts, took advantage of the flexibilities in Article 27(3) of the TRIPS agreement which mandates establishing a protection regime "either by patents or by enacting an effective sui generis system." In light of Articles 7 and 8 of TRIPS, the effectiveness of a plant protection regime established under Article 27 must be judged by its ability to accommodate local/ national welfare and economic goals. Such a reading of the effectiveness requirement fits more comfortably with the other sub-sections of Article 27 which provides that members may choose to protect biological or microbiological materials. Member's flexibility to establish an effective system increases when using a national yardstick. Considering this, India enacted the Protection of Plant Varieties and Farmers Rights Act of 2004 (PPVFA) ${ }^{65}$ under which three separate varieties can be registered, being: (1) New Variety; (2) Extant Variety, which refers to an existing variety discovered for the first time; and (c) Farmer's Variety, based on community property concepts. ${ }^{66}$

i. New variety: A variety would be eligible for protection as new provided it is novel, distinct, uniform, and stable - a threshold similar to the UPOV requirements. ${ }^{67}$ Examination guidelines set out the principles used for testing the distinctiveness, uniformity, and stability (DUS Guidelines) of a variety to determine its registration status. ${ }^{68}$

65 The Protection of Plant Varieties and Farmers' Rights Act, No. 53 of 2001; INDIA CODE (2001), [hereinafter "PPVFA"]

$66 I d, \$ 15(2)$.

67 Id. $\int 15$.

68 See General Guidelines for the Examination of Distinctness, Uniformity and Stability and the Development of Harmonized Descriptions, Protection of Plants Varieties \& 
Information such as (1) the geographical origin of the material; and (2) any contribution by farmer, community, or organization to the development of the variety, (3) information about the use of genetic material conserved by any tribal or rural families in the breeding are required to be given in the application. ${ }^{69}$

ii. Extant Variety: In order to ensure that an appropriate bar is instituted in a country that is rich in biodiversity and traditional farming practices, the extant variety register was created to as a compilation of matters known and existing in the public domain. This classification indirectly creates a higher bar to determine distinctiveness of a new variety. Indeed, the extant variety classification takes care of India's obligation under the Convention on Biological Diversity (CBD) to which it is a signatory. ${ }^{70}$ The Convention requires member states to take adequate steps to preserve biological and genetic materials. Section 28 of the PPVFA provides that the government, as the owner of the extant varieties, enjoys the right to determine their production, sale, marketability, distribution, importation, or exportation. Government ownership over the materials ties in with the objective of protecting biodiversity and allowing the government to negotiate with bioprospectors. An Extant Variety Recommendation Committee (EVRC) develops appropriate procedures for examining applications to register an

Farmers' Rights Authority, Department of Agriculture and Cooperation, Government of India, NASC Complex, IARI, New Delhi-110012 [hereinafter "DUS Guidelines"]

$69 I d . \$ 18(1)(\mathrm{e}), 40$.

70 Convention on Biological Diversity, June 5, 1992, 1760 U.N.T.S. 79 Thereinafter "CBD"]. 
extant variety. ${ }^{71}$ By the end of 2010 , from a pool of 297 applications, 123 extant varieties were registered.

iii. Farmer's Variety: Within this variety typology fall plants which are traditionally cultivated and evolved by the farmers in their fields, or is a wild relative or land race of a variety about which the farmers possess the common knowledge. ${ }^{72}$ The reason for protecting farmers' rights is the underlying assumption that genetic diversity is enhanced when varieties are adapted using traditional farming techniques. ${ }^{73} \mathrm{By}$ 2010, after considering 44 applications three varieties of riceIndrasan, Hansraj, and Tilak Chandan-became the first of the farmer's varieties registered in India, and perhaps, also in the world.

Other features of the PPVFA are all part of the sui generis system that allows a country to tailor a regime that protects plant varieties while making adequate allowances for local issues. The creation of the Gene Fund, for instance, is another feature created by the central government for the benefit of the farmers. ${ }^{74}$ The fund helps reward farmers whose existing variety/material is used as a source to create a new variety. ${ }^{75}$ Similarly, the PPVFA allows farmers to retain their traditional right to save and reuse seeds from their harvests with some restrictions and conditions. The PPVFA has also introduced a right to community compensation in recognition of traditional knowledge contributions. Section 43 reflects a community property

71 See Protection of Plant Varieties and Farmers' Rights Regulations, 2006, Gazette of India, Notification (Dec. 7, 2006).

72 PPVFA, supra note $38, \$ 2(0)$.

$73 \mathrm{Id}$.

74 See PPVFA, supra note 38, §s 39, 45.

75 Id. $\$ 39$. 
philosophy by providing that '[b]reeders wanting to use farmers' varieties for creating essentially derived varieties (EDVs) cannot do so without the express permission of the farmers." 76 Thus, communities can stake a claim of contribution from breeders if a new variety is derived from information or a contribution is made by the local community. ${ }^{77}$ If the community's claim for compensation is established, the breeder must deposit the compensation in the Gene Fund. ${ }^{78}$ Lastly, the PPVFA provides for "benefit sharing" - which refers to sharing a proportion of the benefits accruing to a breeder of a new variety with qualifying claimants, if any, who could be indigenous groups, individuals, or communities. ${ }^{79}$ That concept, first envisaged in the $\mathrm{CBD}$, has been more clearly expounded on the PPVFA and structured to work closely with the community rights principle detailed earlier. Thus, the statute mandates that before registering any new variety, the statutory authority should invite claims for benefit sharing. ${ }^{80}$

\section{CONCLUSION $^{81}$}

Along with the above testimonial, the authors also filed detailed posthearing reports both to the ITC and the USTR addressing questions and concerns that were raised by the Commissioners during the

76 See PPVFA, supra note $38, \$ 48$.

$77 \mathrm{Id}$.

$78 \mathrm{Id}$.

79 Id. $\iint 2(\mathrm{~b}), 26$.

80 Id. $\$ 26$.

81 See Intemational Trade Commission, Report on Investigation No. 332-543, available at http://www.usitc.gov/press_room/news_release/2014/er122211254.htm (for details of the ITC's Report on the Investigation); See also UST'R Special 301 Report, available at www.ustr.gov (for details of the USTR's Report on its Investigation of India's trade practices). 
hearing. The authors highlighted that taking any step that affects India detrimentally will be a strategic mistake for all of the following reasons:

1. India has not done anything during the examination period of this report to warrant changes;

2. Much of industry's requests are unsupported by specific facts and figures;

3. All of India's actions are well-with its negotiated rights under the TRIPS agreement; within established due-processes and procedures;

4. India is one of the few countries in that region where the United States enjoys good public opinion;

5. Other industries, Boeing, being a great example, has no grouse with India and its intellectual property laws.

The authors cautioned both forums forum from setting a course that could result in labelling other countries for exercising their sovereign powers. 